\title{
Occurrences of anti-Toxoplasma gondii and anti-Neospora caninum antibodies in Barbary sheep at Curitiba zoo, southern Brazil
}

\author{
Ocorrências de anticorpos anti-Toxoplasma gondii e anti-Neospora caninum em \\ aoudads no zoológico de Curitiba, sul do Brasil \\ Vivien Midori Morikawa ${ }^{1,2}$; Cristina Kraemer Zimpel ${ }^{1}$; Igor Adolfo Dexheimer Paploski ${ }^{3}$; \\ Maria do Carmo Custódio de Souza Hunold Lara'; Eliana Monteforte Cassaro Villalobos ${ }^{4}$; \\ Adriana Hellmeister de Campos Nogueira Romaldini'; Liria Hiromi Okuda ${ }^{4}$; \\ Alexander Welker Biondo ${ }^{1,2 *}$; Ivan Roque de Barros Filho ${ }^{1}$
}

\begin{abstract}
${ }^{1}$ Departamento de Medicina Veterinária, Universidade Federal do Paraná - UFPR, Curitiba, PR, Brasil
${ }^{2}$ Departamento de Pesquisa e Conservaçáo da Fauna, Secretaria Municipal do Meio Ambiente, Prefeitura Municipal de Curitiba, Curitiba, PR, Brasil

${ }^{3}$ Instituto de Saúde Coletiva, Universidade Federal da Bahia - UFBA, Salvador, BA, Brasil

${ }^{4}$ Instituto Biológico, Centro de Pesquisa e Desenvolvimento de Sanidade Animal, São Paulo, SP, Brasil

Received September 26, 2013

Accepted February 28, 2014
\end{abstract}

\begin{abstract}
Barbary sheep (Ammotragus lervia) have the potential to act as hosts of important infectious diseases, particularly zoonoses. Blood samples from 17 Barbary sheep at the Curitiba zoo were collected to evaluate occurrences of antiToxoplasma gondii and anti-Neospora caninum antibodies, tested using the indirect immunofluorescence antibody test (IFAT). Anti-T. gondii and anti-N. caninum antibodies were detected in 4/17 (23.5\%) and 4/17 (23.5\%) samples, respectively. The present study has shown that Barbary sheep at Curitiba zoo were exposed to T. gondii and N. caninum and therefore may act as intermediate hosts, spreading toxoplasmosis and neosporosis within and between species in shared areas.
\end{abstract}

Keywords: Ammotragus lervia, Toxoplasma gondii, Neospora caninum, zoonoses, zoos.

\section{Resumo}

Aoudads (Ammotragus lervia) têm o potencial para atuar como hospedeiros de importantes doenças infecciosas, em particular as zoonoses. Amostras de sangue de 17 aoudads do zoológico de Curitiba foram coletadas para avaliar ocorrências de anticorpos anti-Toxoplasma gondii e anti-Neospora caninum, testados pela reação de imunofluorescência indireta (RIFI). Anticorpos anti-T. gondii e anti-N. caninum foram detectados em 4/17 (23,5\%) e 4/17 (23,5\%) das amostras dos aoudads, respectivamente. O presente estudo revelou que os aoudads no zoológico de Curitiba estão expostos a T. gondii e $N$. caninum e, portanto, podem atuar como hospedeiros intermediários e fatores de difusáo da toxoplasmose e da neosporose intra e interespécies em áreas compartilhadas.

Palavras-chave: Ammotragus lervia, Toxoplasma gondii, Neospora caninum, zoonoses, zoológicos.

Wildlife may represent a large and often unknown reservoir system that can potentially become a source for emerging or reemerging diseases, particularly zoonoses, which were previously absent or under control (CHOMEL et al., 2007). Although the

\footnotetext{
*Corresponding author: Alexander Welker Biondo

Departamento de Medicina Veterinária, Setor de Ciências Agrárias,

Universidade Federal do Paraná - UFPR, Rua dos Funcionários, 1540, Cabral,

CEP 80035-050, Curitiba, PR, Brasil

e-mail: abiondo@illinois.edu
}

role of wild animals in harboring and transmitting infectious agents has been reported in relation to several species, endangered species may be difficult to assess and therefore their role remains to be fully established. In addition, infectious diseases may also present risks to successful maintenance of wild animals in captivity (YESILBAG et al., 2011).

Translocation or introduction of wild species, particularly exotic ones, which is a regular practice among zoos, may present serious risks to the resident population, since new pathogens 
can be introduced to a hypothetically controlled environment. In such scenarios, zoos may provide an optimal environment for infectious disease transmission because of the greater animal density and sharing of space between different animal species (YESILBAG et al., 2011).

According to some authors, some species in particular, such as the Barbary sheep (Ammotragus lervia), have the potential to act as hosts and reservoirs for important infectious diseases (CANDELA et al., 2009). The Barbary sheep or aoudad was successfully introduced into the United States in the early to mid-twentieth century for the purposes of sport hunting and now is classified as "vulnerable" (VU A2cd) by the IUCN (International Union for Conservation of Nature) (NOWAK, 1999). It is a singular African species that has some unique primitive features and is grouped into the suborder Ruminantia, subfamily of Caprinae, which includes the domesticated genera Capra and Ovis. A closer phylogenetic connection between the genera Ammotragus and Capra was recently observed (MEREU et al., 2008).

In zoos, Toxoplasma gondii infection is important because of the risk of visitor exposure and because animals in captivity may die from clinical toxoplasmosis (DE CAMPS et al., 2008). Regarding neosporosis, which is one of the major causes of abortion in several domestic species (DUBEY, 2003), the wild cycle may present a complicating factor with regard to disease control (ROSYPAL; LINDSAY, 2005). Although toxoplasmosis and neosporosis are important diseases worldwide, the exposure of Barbary sheep to these protozoan pathogens has been scarcely reported to date. Therefore, this study aimed to evaluate occurrences of anti-Toxoplasma gondii and anti-Neospora caninum antibodies in Barbary sheep at Curitiba zoo, state of Paraná, southern Brazil.

Curitiba zoo, which was established in 1982, is now among the largest Brazilian zoos with approximately 2300 specimens, several of which were born in captivity, distributed across an area of 530 square meters (JAVOROUSKI; BISCAIA, 2013). Curitiba $\left(25^{\circ} 25^{\prime} 47^{\prime \prime} \mathrm{S}, 49^{\circ} 16^{\prime} 19^{\prime \prime} \mathrm{W}\right)$ is the capital of the state of Paraná, in southern Brazil, and is the eighth most populous city in Brazil, with an estimated population of 1,751,907 inhabitants (IBGE, 2010).

A total of 17 healthy captive-born Barbary sheep, of both genders and different ages, were included in the present study. Blood samples were taken by means of physical restraint without chemical sedation, following a 24-hour fasting period. Out of the total sample, five of these sheep were kept on display in a public exhibition and 12 were kept in an isolation area. Each individual was identified by means of an ear tag number and color, and the individual information gathered included date of birth, gender and housing location. Blood samples $(20 \mathrm{~mL})$ were collected intravenously and placed in tubes without anti-coagulant and kept at room temperature $\left(25^{\circ} \mathrm{C}\right)$ until visible clot retraction. The material was then centrifuged at $3000 \mathrm{rpm}$ for 5 minutes and the serum was separated and kept at $-20^{\circ} \mathrm{C}$ until testing.

The aliquots were sent to the Biological Institute of São Paulo, Center for Animal Health Research and Development, for serological tests to be performed. The serum samples were tested for anti-Toxoplasma gondii antibodies by means of the indirect immunofluorescence antibody test (IFAT). Each serum sample was tested at a range of dilutions, using a cutoff of 1:64 (CAMARGO, 1974). In addition, individual serum samples were tested for the presence of anti-Neospora caninum antibodies by means of IFAT (DUBEY et al., 1988), on slides for optical microscopy (PGC-Scientifics, catalogue number 60-5453-46) sensitized with tachyzoites of $N$. caninum. Each of these serum samples was tested at a range of dilutions, using a cutoff of 1:50. The specimens were examined under a fluorescence microscope with 40x objective.

Laboratory data were entered into an Excel spreadsheet. Contingency tables for associations were created in Epi Info 7 (CDC, 2013) and then analyzed in OpenEpi (DEAN et al., 2013). Prevalence ratios and 95\% confidence intervals were calculated, and Fisher's exact test was used to compare proportions between variables at a 5\% significance level.

Anti-Toxoplasma gondii and anti-Neospora caninum antibodies were detected, respectively, in 4/17 (23.5\%) and 4/17 (23.5\%) of the sampled Barbary sheep. Only $2 / 17$ (11.7\%) of them showed antibodies simultaneously for $T$. gondii and $N$. caninum.

The prevalences of $T$. gondii and $N$. caninum infection were evaluated stratified by age, gender and place where the animals were housed (public exhibition or isolation area) (Table 1). The mean age of the sampled animals was 4.5 years, with a standard deviation of 2.7 years. Thus, a cutoff of 5 years was chosen to dichotomize the age variable, i.e. forming one group of animals aged less than 5 years and another of animals aged greater than or equal to 5 years.

The prevalence of $T$. gondii infection in animals aged less than 5 years was $2 / 10(20.0 \%)$ and it was $2 / 7(28.6 \%)$ in animals

Table 1. Prevalence of Toxoplasma gondii and Neospora caninum infection stratified by age, gender and housing location.

\begin{tabular}{|c|c|c|c|c|c|c|c|c|}
\hline \multirow{2}{*}{ Characteristic } & \multicolumn{4}{|c|}{ Toxoplasma gondii } & \multicolumn{4}{|c|}{ Neospora caninum } \\
\hline & $\mathrm{n} / \mathrm{N}$ & $\%$ & PR $(95 \% \mathrm{CI})^{*}$ & p-value & $\mathrm{n} / \mathrm{N}$ & $\%$ & PR $(95 \% \mathrm{CI})$ & p-value \\
\hline \multicolumn{9}{|l|}{ Age } \\
\hline$<5$ years & $2 / 10$ & 20.0 & - & - & $2 / 10$ & 20.0 & - & - \\
\hline$\geq 5$ years & $2 / 7$ & 28.6 & $1.4(0.3-7.9)$ & 0.99 & $2 / 7$ & 28.6 & $1.4(0.3-7.9)$ & 0.99 \\
\hline \multicolumn{9}{|l|}{ Sex } \\
\hline Female & $1 / 7$ & 14.3 & - & - & $0 / 7$ & 0.0 & - & - \\
\hline Male & $3 / 10$ & 30.0 & $2.1(0.3-16.3)$ & 0.88 & $4 / 10$ & 40.0 & $\mathrm{NA}^{* *}$ & 0.18 \\
\hline \multicolumn{9}{|l|}{ Place } \\
\hline Isolation area & $1 / 12$ & 8.3 & - & - & $2 / 12$ & 16.7 & - & - \\
\hline Public display & $3 / 5$ & 60.0 & $7.2(0.9-53.6)$ & 0.10 & $2 / 5$ & 40.0 & $2.4(0.5-12.6)$ & 0.38 \\
\hline
\end{tabular}

${ }^{*}$ Prevalence ratio /confidence interval; ${ }^{* *}$ Not applicable; $\mathrm{n}=$ Total number of seropositive animals; $\mathrm{N}=$ Total number of sampled animals. 
aged greater than or equal to 5 years, which corresponded to a prevalence ratio of 1.4 (95\% CI: 0.3-7.9), i.e. higher in the group of animals aged greater than or equal to 5 years, although this difference was not statistically significant (Fisher p-value $=0.99)$. The same values were obtained when $N$. caninum infection and the animals' ages were evaluated.

Regarding gender, the $T$. gondii prevalence in females was $1 / 7$ $(14.3 \%)$ and it was $3 / 10(30.0 \%)$ in males, making the prevalence in males 2.1 times (95\% CI: 0.3-16.3) greater in males than in females, but this difference was not statistically significant (Fisher p-value $=0.88)$. The $N$. caninum prevalence was $0 / 7(0 \%)$ in females and 4/10 (40.0\%) in males. Since the prevalence in one group was zero, it was not possible to calculate the prevalence ratio.

The T. gondii prevalence among the animals housed in the isolation area was $1 / 12(8.3 \%)$ and among the animals on public display it was $3 / 5(60.0 \%)$. The prevalence of $T$. gondii in the animals on public display was 7.2 times (95\% CI: 0.9-53.6) greater than in the animals kept in isolation. This difference was not statistically significant, but was close to the significance threshold (Fisher p-value $=0.10)$. For $N$. caninum, the prevalence among animals housed in the isolation area was $2 / 12$ (16.7\%) and among animals on public display it was $2 / 5(40.0 \%)$. The prevalence was 2.4 times (95\% CI: $0.5-12.6)$ greater in the animals on public display than in the animals in the isolation area, even though this difference was not statistically significant (Fisher p-value $=0.38$ ).

The present study has revealed occurrences of two important infectious agents in Barbary sheep, which are a singular wild species that shares a common ancestor with domestic species in the genera Capra and Ovis (MEREU et al., 2008). Emerging and reemerging infectious diseases may have a major effect and impact on human and animal health, and produce economic losses. Animals, particularly of wild species, are thought to be reservoirs for more than $70 \%$ of all emerging infections (KUIKEN et al., 2005; CHOMEL et al., 2007). Pet zoos, where children are allowed to approach and feed captive wild and domestic animals, have been linked to several zoonotic outbreaks. Not surprisingly, over 25 outbreaks of human infectious diseases associated with visitors to animal exhibits were identified from 1990 to 2000 (BENDER; SHULMAN, 2004; CHOMEL et al., 2007).

Antibodies against T. gondii were at higher levels in the current report than in the first previous report, and were present in 4/17 $(23.5 \%)$ versus $1 / 10(10.0 \%)$ of the Barbary sheep, respectively (GAUSS et al., 2006). The differences may be due to different geographical locations, which were reported in the earlier study to be the most important factor affecting infection prevalence. Similar results of 6/25 (24.0\%) for captive Barbary sheep were found more recently, while the prevalence among free-range Barbary sheep was 1/67 (1.5\%) (CANDELA et al., 2009).

Since Curitiba zoo is located in a humid subtropical climate with an average annual temperature of $16^{\circ} \mathrm{C}$, the relatively higher prevalence may be associated with the local weather (IBGE, 2010). Our findings corroborate previous studies that have shown that there may be higher prevalence of toxoplasmosis infection in areas that are more shaded and have relatively higher humidity than in areas with lower shade and rain and higher evaporation and desiccation (SMITH; FRENKEL, 1995; GAUSS et al., 2006). Although age, gender and housing location were not statistically significant, the Barbary sheep on public display were 7.2 times more likely to have $T$. gondii infection than were those housed in the isolation area. Hence, captive animals on public display in open enclosures may be at higher risk of infection, as previously observed (DE CAMPS et al., 2008). Since the prevalence of T. gondii infection also depends on the presence of felids (GAUSS et al., 2006), our study may provide a warning with regard to nearby wild cat enclosures and circulation of domestic felids in zoo areas.

Neospora caninum co-infection was also investigated because previous studies reported multiple infections in animal populations (PETNEY; ANDREWS, 1998; CANDELA et al., 2009). Although neosporosis was first reported in wild animals in a dead blacktailed deer (WOODS et al., 1994), and antibodies have recently been reported in Barbary sheep (ALMERÍA et al., 2007) and several other free-range and captive wild animals, the role of wild animals in the $N$. caninum life cycle remains unclear (DUBEY, 2003; ALMERÍA et al., 2007). Although antibodies against $N$. caninum in the present study occurred in $4 / 17$ animals $(23.5 \%)$, i.e. more frequently than in a previous survey, which found them in 1/13 Barbary sheep (7.7\%), no significant differences regarding gender or age were observed in either study (ALMERÍA et al., 2007). Both studies used the indirect immunofluorescence test (IFAT), with 1:50 as the cutoff (CHEADLE et al., 1999; ORTUNO et al., 2002).

T. gondii and N. caninum occurrences in Barbary sheep can be compared with occurrences in domestic goats, which are genetically related to each other (MEREU et al., 2008). Our findings may indicate, as observed in domestic goats, that males and females are equally exposed to the risk of infection (FARIA et al., 2007). However, other factors such as geographical area and environmental exposure may impede adequate comparison, as observed among domestic goats in northeastern Brazil, which presented higher occurrence of $T$. gondii $(75 / 306 ; 24.5 \%)$ and lower occurrence of $N$. caninum (10/306; 3.3\%) (FARIA et al., 2007). Similar rates among domestic goats were also observed in another study in southeastern Brazil, which showed higher occurrence of $T$. gondii $(113 / 394 ; 28.7 \%)$ and lower occurrence of $N$. caninum (25/394; 6.4\%) (FIGLIUOLO et al., 2004). These differences may be explained by the level of exposure and climatic factors, thus reflecting the abundance of viable parasitic stages in the environment and influencing the overall prevalence (FARIA et al., 2007).

Captive wild species, particularly carnivores kept in zoos, may share environments and act as sources of $T$. gondii and $N$. caninum infection for herbivores such as Barbary sheep or other related susceptible wild species. A recent study conducted among wild captive carnivores kept in zoos in the Brazilian states of São Paulo and Mato Grosso, and in Brasilia, showed that antibodies to T. gondii and $N$. caninum were present in 102/161 (63.4\%) and 70/161 (50.3\%) wild cats, respectively, using IFAT. In addition, 49/98 (50.5\%) and 40/98 (41.2\%) wild canids were seropositive for $T$. gondii and $N$. caninum antigens, respectively, using IFAT (ANDRE et al., 2010). Relatively lower prevalence was found in wild canids in zoos and sanctuaries in the states of Paraná, Santa Catarina and Rio de Janeiro and in Brasilia, which found prevalences of 20/50 (40.0\%) for T. gondii and $18 / 50(36.0 \%)$ for $N$. caninum (MATTOS et al., 2008). More 
recently, seropositivity for $T$. gondii was observed in 38/57 samples (66.7\%) samples from Neotropical felids kept at the Bela Vista Biological Sanctuary, Itaipu Binacional hydroelectric development, southern Brazil (ULLMANN et al., 2010), which was similar to the prevalence of $26 / 37$ (64.4\%) that was found in an early study on captive exotic wild felids in 12 different zoos (SILVA et al., 2001). Overall, these results suggest that despite efforts to control such infections in zoo facilities, particularly among wild-caught carnivore specimens, animals may be exposed to infectious agents due to other environmental sources.

Although T. gondii seroprevalence may be associated with several risk factors, particularly the presence of domestic cats, a comprehensive study conducted on 865 Neotropical felids in 78 cities in 20 Brazilian states showed that the presence of domestic cats roaming in zoos was not an independent risk factor for toxoplasmosis (RAMOS SILVA et al., 2007). Moreover, the seroprevalence of T. gondii and $N$. caninum in roaming and/or feral cats has not been documented to date in Brazilian zoos, and further studies should be conducted in order to fully establish the role of domestic cats as potential sources of infection among captive wild animals.

Finally, reports of wild species that could serve as intermediate hosts for $N$. caninum have been gradually increasing. These species include Barbary sheep, many other ruminant species and possibly rhinoceroses, thus providing new insights into current questions regarding the $N$. caninum cycle in wildlife (GONDIM, 2006).

In conclusion, this study has shown that Barbary sheep in Curitiba zoo, Paraná, southern Brazil, are exposed to $T$. gondii and $N$. caninum and may act as intermediate hosts for spreading toxoplasmosis and neosporosis. Barbary sheep may play an important role in the protozoan cycle as a sentinel for measuring parasite dissemination in zoos and for checking whether circulating pathogens are present. In addition, wildlife staff should be aware of the inherent risks involved in introducing and providing shelter for such animal species. A better understanding of pathogen occurrence in wildlife species, particularly zoonotic pathogens, may serve as the basis for future environmental protection and public health strategies.

\section{Acknowledgements}

The authors deeply thank the Curitiba Zoo personnel, particularly Dr. Tereza Cristina Castellano Margarido and Dr. Maysa Pellizzaro for restraining and handling the Barbary sheep, and Jeffrey Thrush for the overall English review.

\section{References}

Almería S, Vidal D, Ferrer D, Pabón M, Fernández-de-Mera MI, RuizFons F, et al. Seroprevalence of Neospora caninum in non-carnivorous wildlife from Spain. Vet Parasitol 2007; 143(1): 21-28. PMid:16962706. http://dx.doi.org/10.1016/j.vetpar.2006.07.027

Andre MR, Adania CH, Teixeira RH, Silva KF, Jusi MM, Machado ST, et al. Antibodies to Toxoplasma gondii and Neospora caninum in captive neotropical and exotic wild canids and felids. J Parasitol 2010; 96(5): $1007-$ 1009. PMid:20950109. http://dx.doi.org/10.1645/GE-2502.1
Bender JB, Shulman SA. Reports of zoonotic disease outbreaks associated with animal exhibits and availability of recommendations for preventing zoonotic disease transmission from animals to people in such settings. $J$ Am Vet Med Assoc 2004; 224(7): 1105-1109. http://dx.doi.org/10.2460/ javma.2004.224.1105

Camargo ME. Introdução às técnicas de imunofluorescência. Rev Bras Patol Clin 1974; 10(4): 143-171.

Candela MG, Serrano E, Martinez-Carrasco C, Martín-Atance P, Cubero MJ, Alonso F, et al. Coinfection is an important factor in epidemiological studies: the first serosurvey of the aoudad (Ammotragus lervia). Eur J Clin Microbiol Infect Dis 2009; 28(5): 481-489. PMid:19020912. http:// dx.doi.org/10.1007/s10096-008-0654-8

Centers for Disease Control and Prevention - CDC. Epi Info [online]. 2013 [cited 2013 Jul 03]. Available from: http://wwwn.cdc. gov/epiinfo/7/.

Cheadle MA, Lindsay DS, Blagburn BL. Prevalence of antibodies to Neospora caninum in dogs. Vet Parasitol 1999; 85(4): 325-330. http:// dx.doi.org/10.1016/S0304-4017(99)00105-3

Chomel BB, Belotto A, Meslin FX. Wildlife, exotic pets, and emerging zoonoses. Emerg Infect Dis 2007; 13(1): 6-11. PMid:17370509 PMCid:PMC2725831. http://dx.doi.org/10.3201/eid1301.060480

De Camps S, Dubey JP, Saville WJ. Seroepidemiology of Toxoplasma gondii in zoo animals in selected zoos in the midwestern United States. J Parasitol 2008; 94(3): 648-653. PMid:18605803. http://dx.doi. org/10.1645/GE-1453.1

Dean AG, Sullivan KM, Soe MM. Open Source Epidemiologic Statistics for Public Health. OpenEpi; 2013 [cited 2013 Jul 03]. Available from: http://www.OpenEpi.com

Dubey JP. Review of Neospora caninum and neosporosis in animals. Korean J Parasitol 2003; 41(1): 1-16. PMid:12666725 PMCid:PMC2717477. http://dx.doi.org/10.3347/kjp.2003.41.1.1

Dubey JP, Carpenter JL, Speer CA, Topper MJ, Uggla A. Newly recognized fatal protozoan disease of dogs. J Am Vet Med Assoc 1988; 192(9): 12691285. PMid:3391851.

Faria EB, Gennari SM, Pena HF, Athayde AC, Silva ML, Azevedo SS. Prevalence of anti-Toxoplasma gondii and anti-Neospora caninum antibodies in goats slaughtered in the public slaughterhouse of Patos city, Paraiba State, Northeast region of Brazil. Vet Parasitol 2007; 149(1-2): 126-129. PMid:17706359. http://dx.doi.org/10.1016/j.vetpar.2007.07.009

Figliuolo LPC, Rodrigues AAR, Viana RB, Aguiar DM, Kasai N, Gennari SM. Prevalence of anti-Toxoplasma gondii and antiNeospora caninum antibodies in goat from São Paulo State, Brazil. Small Rum Res 2004; 55(1-3): 29-32. http://dx.doi.org/10.1016/j. smallrumres.2003.12.013

Gauss CB, Dubey JP, Vidal D, Cabezón O, Ruiz-Fons F, Vicente J, et al. Prevalence of Toxoplasma gondii antibodies in red deer (Cervus elaphus) and other wild ruminants from Spain. Vet Parasitol 2006; 136(3-4): 193-200. PMid:16359801. http://dx.doi.org/10.1016/j.vetpar.2005.11.013

Gondim LF. Neospora caninum in wildlife. Trends Parasitol2006; 22(6): $247-$ 252. PMid:16616642. http://dx.doi.org/10.1016/j.pt.2006.03.008

Instituto Brasileiro de Geografia e Estatística - IBGE. Population estimates for Curitiba. IBGE; 2010 [cited 2013 Jun 30]. Available from: http:// www.ibge.gov.br/cidadesat/painel/painel.php?codmun=410690.

Javorouski ML, Biscaia SA. Zoológico municipal de Curitiba 30 anos. Curitiba: Editora Juruá; 2013. PMid:23272356. 
Kuiken T, Leighton FA, Fouchier RA, LeDuc JW, Peiris JS, Schudel A, et al. Public health. Pathogen surveillance in animals. Science 2005; 309(5741): 1680-1681. PMid:16150997. http://dx.doi. org/10.1126/science. 1113310

Mattos BC, Patricio LL, Plugge NF, Lange RR, Richartz RR, Dittrich RL. Seroprevalence of antibodies anti-Neospora caninum and anti-Toxoplasma gondii in captive wild canids. Rev Bras Parasitol Vet 2008; 17(S1): 267-272. PMid:20059860.

Mereu P, Palici di Suni M, Manca L, Masala B. Complete nucleotide mtDNA sequence of Barbary sheep (Ammotragus lervia). DNA Seq 2008; 19(3): 241-245. PMid:17852329. http://dx.doi. org/10.1080/10425170701550599

Nowak RM. Walker's mammals of the world. Baltimore: Johns Hopkins Univesity Press; 1999.

Ortuńo A, Castellà J, Almería S. Seroprevalence of antibodies to Neospora caninum in dogs from Spain. J Parasitol 2002; 88(6): 1263-1266. http:// dx.doi.org/10.1645/0022-3395(2002)088[1263:SOATNC]2.0.CO;2

Petney TN, Andrews RH. Multiparasite communities in animals and humans: frequency, structure and pathogenic significance. Int $J$ Parasitol 1998; 28(3): 377-393. http://dx.doi.org/10.1016/S00207519(97)00189-6

Ramos Silva JC, Marvulo MF, Dias RA, Ferreira F, Amaku M, Adania $\mathrm{CH}$, et al. Risk factors associated with sero-positivity to Toxoplasma gondii in captive neotropical felids from Brazil. Prev
Vet Med 2007; 78(3-4): 286-295. PMid:17140683. http://dx.doi. org/10.1016/j.prevetmed.2006.10.013

Rosypal AC, Lindsay DS. The sylvatic cycle of Neospora caninum: where do we go from here? Trends Parasitol 2005; 21(10): 439-440. PMid:16098812. http://dx.doi.org/10.1016/j.pt.2005.08.003

Silva JC, Ogassawara S, Adania CH, Ferreira F, Gennari SM, Dubey JP, et al. Seroprevalence of Toxoplasma gondii in captive neotropical felids from Brazil. Vet Parasitol 2001; 102(3): 217-224. http://dx.doi. org/10.1016/S0304-4017(01)00523-4

Smith DD, Frenkel JK. Prevalence of antibodies to Toxoplasma gondii in wild mammals of Missouri and east central Kansas: biologic and ecologic considerations of transmission. JWildl Dis 1995; 31(1): 15-21. PMid:7563419. http://dx.doi.org/10.7589/0090-3558-31.1.15

Ullmann LS, Silva RC, Moraes W, Cubas ZS, Santos LC, Hoffmann JL, et al. Serological survey of Toxoplasma gondii in captive Neotropical felids from Southern Brazil. Vet Parasitol 2010; 172(1-2): 144-146. PMid:20472340. http://dx.doi.org/10.1016/j.vetpar.2010.04.013

Woods LW, Anderson ML, Swift PK, Sverlow KW. Systemic neosporosis in a California black-tailed deer (Odocoileus hemionus columbianus). J Vet Diagn Invest 1994; 6(4): 508-510. PMid:7858040. http://dx.doi. org/10.1177/104063879400600425

Yesilbag K, Alpay G, Karakuzulu H. A serologic survey of viral infections in captive ungulates in Turkish zoos. J Zoo Wildl Med 2011; 42(1): 44-48. PMid:22946369. http://dx.doi.org/10.1638/2010-0009.1 